\title{
Development and validation of an HPLC method for the determination of hyaluronic acid active substance in pharmaceutical formulations
}

\author{
Emre Şefik ÇAĞLAR ${ }^{1}$ (D), Neslihan ÜSTÜNDAĞ OKUR ${ }^{1^{*}}$ (D), Hatice Yeşim KARASULU ${ }^{2}$ (D) \\ 1 Department of Pharmaceutical Technology, Faculty of Pharmacy, University of Health Sciences, İstanbul, Turkey. \\ 2 Department of Pharmaceutical Technology, Faculty of Pharmacy, Ege University, İzmir, Turkey. \\ * Corresponding Author. E-mail: neslihanustundag@yahoo.com (N.Ü.O.); Tel. +90-216-418 9616.
}

Received: 03 March 2021 / Revised: 06 September 2021/ Accepted: 07 September 2021

\begin{abstract}
It is an analytical requirement to identify and determine high molecular weight APIs in pharmaceutical forms. For this reason, it is aimed to develop and validate an analytical method for the determination of hyaluronic acid in pharmaceutical form in this study. $0.1 \mathrm{M} \mathrm{Na}_{2} \mathrm{SO}_{4}$ was prepared as mobile phase. The separation of compound was performed with a OHpak Shodex SB-806M HQ (13 $\mu \mathrm{m}, 8,0 \times 300 \mathrm{~mm}$, Japan) analytical column. Guard column which is OHpak SB-G, $(8 \mu \mathrm{m}, 100 \AA$, $6.0 \times 50 \mathrm{~mm}$, Japan) was integrated to the system before the analytical column. UV detection at $198 \mathrm{~nm}$ was used to monitor the eluent and flow rate of the mobile phase was set to $1 \mathrm{~mL} / \mathrm{min}$. The method has been validated in terms of system suitability, linearity, limits of detection (LOD) and quantity (LOQ), precision, accuracy, specificity, selectivity, and stability. The obtained findings showed that the analytical method has linearity higher than 0.99 , accuracy, precision, selectivity and stability. The method was found to be precise, accurate and specific during the study.
\end{abstract}

KEYWORDS: Hyaluronic acid; HPLC-UV; microemulsion; analytical method; validation.

\section{INTRODUCTION}

In 1934, Karl Meyer and John Palmer described a new glucosamine isolation procedure from the vitreous of the bovine eye [1]. This high molecular weight polysaccharide consisting of N-acetyl Dglucosamine and D-glucuronic acid has been named as hyaluronic acid (HA) (Figure 1) [1,2]. HA produced by synovial cells, fibroblasts and chondrocytes [2] is found in synovial fluid, skin, umbilical cord and vitreous part of the eye [3] and HA has been successfully isolated from biological sources such as umbilical cord, skin, synovial fluid, Streptococcus bacteria in later years [3]. In addition, HA is identical to all living organisms and is highly biocompatible. Due to its unique viscoelasticity and limited immunogenicity, HA and its derivatives have many clinical and preclinical applications such as drug delivery and drug targeting [1,3]. It is especially used as viscosupplement in the treatment of osteoarthritis and as an adjunct in eye surgery and also in wound regeneration. Today, many studies are conducted on nasal, oral, pulmonary, ophthalmic, topical, parenteral, and tissue engineering applications of HA [1,4-6].

$\mathrm{HA}$ is a disaccharide polymer that is composed of D-glucuronic acid and D-N-acetylglucosamine and linked by variable $\beta-1,4$ and $\beta-1,3$ glycosidic bonds and chains up to $8000 \mathrm{kDa}$, called high molecular weight HA (HMW-HA). HA can be as long as 25,000 disaccharide repeats. The size of sodium hyaluronate polymers can range from 5000 to 20,000,000 Da in vivo. HMW-HA has an immunosuppressive effect while its low molecular weight has the opposite effect leading to activation of the immune system $[7,8]$. Due to HA widely used in pharmaceutical and cosmetic products, the determination of HA in these products plays an essential role in terms of fruitful drug development. Until now, several different determination methods of HA $[7,9]$ were developed and most of the reported methods are by derivatization but the effectiveness of the developed methods was not beneficial for pharmaceutical procedures in terms of being simple, accurate, precise, and sensitive.

How to cite this article: Çağlar EŞ, Üstündağ Okur N, Karasulu HY. Development and validation of an HPLC method for the determination of hyaluronic acid active substance in pharmaceutical formulations. J Res Pharm. 2022; 26(1): 112-122. 
Compared to derivation, size exclusion chromatographic methods have the advantages of reducing analysis time, increasing sensitivity and flexibility, and lowering the cost of instruments and maintenance. One of the biggest disadvantages of derivatization is the lack of stability. The reaction products are unstable and probably have short half-lives due to spontaneous intermolecular rearrangement $[9,10]$.

Microemulsions are homogeneous, transparent; thermodynamically stable dispersions, optically isotropic oil and water system stabilized with a suitable surfactant and co-surfactant [11]. Several pharmaceutical advantages, such as ease of preparation, transparency, and the potential to dissolve various drugs can be seen as advantages of microemulsions [12]. Surfactants are highly preferred to create these microheterogeneous systems. They may cause changes in many parameters of these microstructure systems, even if they are used in very small amounts. For all these reasons, there is a need to develop a useful analytical method for the separation and identification of drugs loaded on these systems [13]. Considering all these, this study aimed to develop a simple, specific, accurate, fast, precise HPLC method for the determination of HA in pharmaceutical and cosmetic products based on UV-detection.

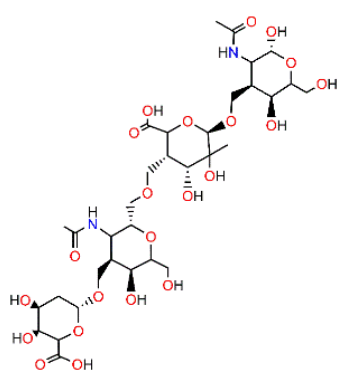

Figure 1. Chemical structure of hyaluronic acid.

\section{RESULTS AND DISCUSSION}

One of the most essential tools in terms of evaluating drug products is HPLC. Synthesis, manufacturing, and storage of the drug molecule and pharmaceutical formulation can cause drug-related impurities or degradants. This is the reason why an HPLC method should be able to separate, detect, and quantify the drugs and drug-related components as previously mentioned degradants and impurities. Knowing the performance characteristics and limitations and therefore the experimental and environmental effects that can change these characteristics are playing a key role in terms of method validation. So, the process that covers all the period of determination performance characteristics and limitations is being called as validation [14]. A method developed for an HPLC procedure must accurate, sensitive, and able to identify an analyte with high selectivity. For this purpose, validation of analytical methods should include assessments of linearity, selectivity, accuracy (recovery), precision, LOD, LOQ, and measurement uncertainty [15].

In our study, the UV spectrum of the HA in the mobile phase was scanned in the region between 190 and 800 $\mathrm{nm}$. The $\lambda_{\max }$ value was determined as $198 \mathrm{~nm}$ (Figure 5).

The linearity of the method was observed in the concentration range of 5 to100 $\mu \mathrm{g} / \mathrm{ml}$, demonstrating its suitability. Each experiment at all concentrations was repeated three times on three separate samples to obtain the calibration data. The area value observed in HPLC was plotted against concentration and the calibration curve was drawn. The equation of the line and the correlation coefficient $\left(R^{2}\right)$ value were calculated. $\mathrm{R}^{2}$ indicating the functional linear relationship between the concentration of analyte and the area under the peak was above 0.999 across the concentration range used. The correct equation has been found as $\mathrm{y}=6.8294 \mathrm{X}$ +2.9334 . The $\mathrm{R}^{2}$ value was determined as 0.9996. The Calibration graph is shown in Figure 2.

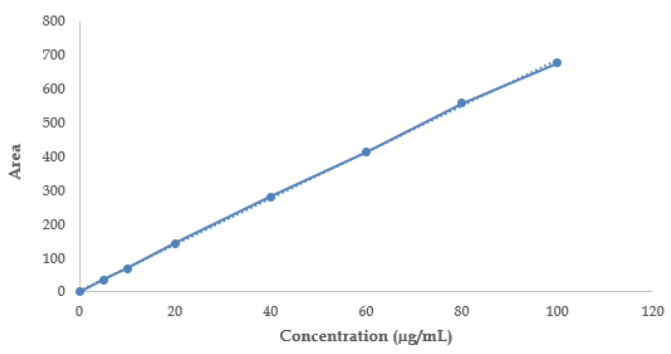

Figure 2. Calibration curve based on chromatographic data of hyaluronic acid. 
Precision studies are performed for an analytical procedure to express the proximity between measurement sequences obtained from the same homogeneous samples under the same conditions. For analytical method validation following $\mathrm{ICH}$ guidelines, the solution at the lowest, middle, and top concentrations of the working range $(5 \mu \mathrm{g} / \mathrm{mL}, 60 \mu \mathrm{g} / \mathrm{mL}$ and $100 \mu \mathrm{g} / \mathrm{mL})$ was measured ten times consecutively, and mean, standard deviation (SD), coefficient of variation (RSD) (\%), accuracy (\%), precision values were calculated. The results obtained are shown in Table 1.

Table 1. Calculation of accuracy and precision values at the lowest and highest concentrations of the working range for the results of the precision study and analytical method validation as a result of HPLC data.

\begin{tabular}{|c|c|c|c|}
\hline No & $\begin{array}{c}\text { Theoretical } \\
\text { Concentration } \\
(\mu \mathrm{g} / \mathrm{mL})\end{array}$ & Area & $\begin{array}{c}\text { Practical } \\
\text { Concentration } \\
(\mu \mathrm{g} / \mathrm{mL}) \\
\end{array}$ \\
\hline 1 & \multirow{10}{*}{$5 \mu \mathrm{g} / \mathrm{mL}$} & 37.88 & 5.117 \\
\hline 2 & & 38.02 & 5.138 \\
\hline 3 & & 37.20 & 5.018 \\
\hline 4 & & 37.61 & 5.078 \\
\hline 5 & & 37.55 & 5.069 \\
\hline 6 & & 37.91 & 5.121 \\
\hline 7 & & 37.25 & 5.025 \\
\hline 8 & & 37.23 & 5.022 \\
\hline 9 & & 37.71 & 5.092 \\
\hline \multirow[t]{5}{*}{10} & & 37.01 & 4.990 \\
\hline & & Mean & 5.067 \\
\hline & & SD & 0.051 \\
\hline & & RSD \% & 1.007 \\
\hline & & Accuracy \% & 101.34 \\
\hline 1 & \multirow{10}{*}{$60 \mu \mathrm{g} / \mathrm{mL}$} & 415.00 & 60.337 \\
\hline 2 & & 419.52 & 60.999 \\
\hline 3 & & 412.50 & 59.971 \\
\hline 4 & & 410.24 & 59.640 \\
\hline 5 & & 411.08 & 59.763 \\
\hline 6 & & 41824 & 60.812 \\
\hline 7 & & 405.86 & 58.999 \\
\hline 8 & & 417.67 & 60.728 \\
\hline 9 & & 417.62 & 60.721 \\
\hline \multirow[t]{5}{*}{10} & & 408.43 & 59.375 \\
\hline & & Mean & 60.611 \\
\hline & & SD & 0.907 \\
\hline & & RSD \% & 1.497 \\
\hline & & Accuracy \% & 101.018 \\
\hline 1 & \multirow{10}{*}{$100 \mu \mathrm{g} / \mathrm{mL}$} & 687.81 & 100.284 \\
\hline 2 & & 696.40 & 101.541 \\
\hline 3 & & 687.06 & 100.174 \\
\hline 4 & & 682.66 & 99.529 \\
\hline 5 & & 680.74 & 99.248 \\
\hline 6 & & 680.28 & 99.181 \\
\hline 7 & & 680.13 & 99.159 \\
\hline 8 & & 678.39 & 98.904 \\
\hline 9 & & 686.90 & 100.150 \\
\hline \multirow[t]{5}{*}{10} & & 687.20 & 100.191 \\
\hline & & Mean & 99.837 \\
\hline & & SD & 0.792 \\
\hline & & RSD \% & 0.793 \\
\hline & & Accuracy \% & 99.836 \\
\hline
\end{tabular}

As Table 1 shows, the percentage of accuracy values for 5,60 and $100 \mu \mathrm{g} / \mathrm{mL}$ solutions were found 101.34, 101.018 and 99.836, respectively, for bulk HA solution. Obtained results showed that the accuracy percentage was approximately $100 \%$ and the standard deviation was less than $2 \%$ which is the acceptance criteria. According to these results, the analysis system for the determination is verified. In addition, the repeatability of the measurements was denoted as high due to the low values of standard deviation. Evaluation of these results highlights that the equipment used for the study was correct and hence the developed analytical method is highly repetitive. The accuracy of the method in this calculation has been confirmed by calculating the average recovery (\%) values. SD and RSD\% values were also calculated for this parameter. Area values of three parallel samples at three different concentrations $(20,40$ and $60 \mu \mathrm{g} / \mathrm{mL})$ were 
measured. The concentration amount corresponding to this area value was found by placing it in the calibration equation. Accuracy and recoverability results are shown in Table 2.

Table 2. Accuracy and recoverability study results as a result of HPLC study ( $p>0.05)$.

\begin{tabular}{|c|c|c|c|c|c|}
\hline $\begin{array}{c}\text { Theoretical } \\
\text { Concentration } \\
(\mu \mathrm{g} / \mathrm{mL})\end{array}$ & Area-1 & Area- 2 & Area-Mean & $\begin{array}{c}\text { Practical } \\
\text { Concentration } \\
(\mu \mathrm{g} / \mathrm{mL})\end{array}$ & $\begin{array}{c}\text { Recovery } \\
(\%)\end{array}$ \\
\hline 20 & 143.59 & 141.45 & 142.52 & 20.439 & 102.194 \\
\hline 20 & 137.56 & 144.22 & 140.89 & 20.200 & 101.002 \\
\hline \multirow[t]{4}{*}{20} & 139.91 & 141.36 & 140.64 & 20.163 & 100.815 \\
\hline & & & Mean & 20.267 & 101.337 \\
\hline & & & SD & 0.122 & 0.610 \\
\hline & & & RSD \% & 0.602 & 0.602 \\
\hline 40 & 272.82 & 277.92 & 275.37 & 39.892 & 99.729 \\
\hline 40 & 270.24 & 266.63 & 268.44 & 38.876 & 97.191 \\
\hline \multirow[t]{4}{*}{40} & 272.71 & 271.73 & 272.22 & 39.430 & 98.576 \\
\hline & & & Mean & 39.399 & 98.499 \\
\hline & & & SD & 0.415 & 1.038 \\
\hline & & & RSD \% & 1.054 & 1.054 \\
\hline 60 & 408.43 & 405.86 & 407.145 & 59.187 & 98.645 \\
\hline 60 & 406.79 & 404.96 & 405.875 & 59.001 & 98.335 \\
\hline \multirow[t]{4}{*}{60} & 410.24 & 411.08 & 410.660 & 59.702 & 98.503 \\
\hline & & & Mean & 59.297 & 98.828 \\
\hline & & & SD & 0.363 & 0.605 \\
\hline & & & RSD \% & 0.612 & 0.612 \\
\hline
\end{tabular}

The mean recovery data of HA in samples were $101.337,98.499$ and $98.828 \%$, respectively. The mean R.S.D. (\%) was found $0.612,1.054$ and 0.612 . R.S.D \% results were found as acceptable for the study. Recovery (\%) of HA is given in Table 2. The average of the concentrations, $\mathrm{SD}$ and $\mathrm{RSD} \%$, corresponding to the area value injected into the HPLC for ten consecutive times of the solutions at a concentration of $40 \mu \mathrm{g} / \mathrm{mL}$ and prepared on two different days were calculated. The results obtained are shown in Table 3 . The fact that the method is repeatable shows that the RSD \% is less than $2 \%$.

Table 3. Repeatability study results based on HPLC data.

\begin{tabular}{|c|c|c|c|c|c|c|c|}
\hline No & $\begin{array}{c}\text { Theoretical } \\
\text { Concentration } \\
(\mu \mathrm{g} / \mathrm{mL})\end{array}$ & Area & $\begin{array}{c}\text { Practical } \\
\text { Concentration } \\
(\mu \mathrm{g} / \mathrm{mL})\end{array}$ & No & $\begin{array}{c}\text { Theoritical } \\
\text { Concentration } \\
(\mu \mathrm{g} / \mathrm{mL})\end{array}$ & Area & $\begin{array}{c}\text { Practical } \\
\text { Concentration } \\
(\mu \mathrm{g} / \mathrm{mL}) \\
\end{array}$ \\
\hline 1 & 40 & 279.83 & 40.545 & TE-2-1 & 40 & 287.37 & 41.649 \\
\hline 2 & 40 & 286.07 & 41.458 & TE-2-2 & 40 & 296.53 & 42.990 \\
\hline 3 & 40 & 286.52 & 41.524 & TE-2-3 & 40 & 292.49 & 42.399 \\
\hline 4 & 40 & 294.74 & 42.728 & TE-2-4 & 40 & 294.37 & 42.674 \\
\hline 5 & 40 & 288.86 & 41.867 & TE-2-5 & 40 & 294.48 & 42.690 \\
\hline 6 & 40 & 282.80 & 40.980 & TE-2-6 & 40 & 298.28 & 43.246 \\
\hline 7 & 40 & 293.01 & 42.475 & TE-2-7 & 40 & 288.33 & 41.789 \\
\hline 8 & 40 & 284.27 & 41.195 & TE-2-8 & 40 & 294.50 & 42.693 \\
\hline 9 & 40 & 293.87 & 42.601 & TE-2-9 & 40 & 295.27 & 42.806 \\
\hline \multirow[t]{4}{*}{10} & 40 & 287.33 & 41.643 & TE-2-10 & 40 & 307.70 & 44.626 \\
\hline & & AVE & 41.702 & & & AVE & 42.756 \\
\hline & & SD & 0.685 & & & SD & 0.781 \\
\hline & & RSD \% & 1.643 & & & RSD \% & 1.826 \\
\hline
\end{tabular}


For the reproducibility study, the area values of ten $20 \mu \mathrm{g} / \mathrm{mL}$ solutions prepared by 2 different analysts were tested and the mean, SD, and RSD\% of the obtained values were calculated. The results obtained are shown in Table 4 . It shows that the method is less than $2 \%$ of the RSD that is available again. There was no significant difference between the area values calculated from ten injections for $20 \mu \mathrm{g} / \mathrm{mL}$ concentration ( $\mathrm{p}>$ 0.05). The Limit of Detection (LOD) and Limit of Quantitation (LOQ) tests for the procedure are performed on samples containing very low concentrations of analyses. In the calibration equation, the SD values of the areas corresponding to the lowest value were calculated and the average of these values was divided by the slope of the selected calibration curve and multiplied by 3.3 and the detection limit was determined by multiplying the detection limit by 10. In LOD and LOQ studies, 3 samples were studied. The results obtained are shown in The solution of HA active substance, which was prepared at a concentration of 60 $\mu \mathrm{g} / \mathrm{mL}$ using the mobile phase, was measured in HPLC at 15, 30, 60 and 120 minutes and 24 and 48 hours and it was determined whether there was any change in the values. The results obtained are shown in Table 6.

The specificity of the HPLC method is demonstrated by the separation of the analytes from other potential components such as impurities, degradants, or excipients [16, 17]. In this regard, the optimum amount of contents in microemulsion formulation for IPM, Tween 80, ethanol and $0.9 \% \mathrm{NaCl}$ solution were found $7.02 \%, 25.575 \%, 25.575 \%, 41.83 \%$, respectively.

Table 5Table 4. Reproductivity study results based on HPLC data.

\begin{tabular}{|c|c|c|c|c|c|c|}
\hline \multirow{14}{*}{ 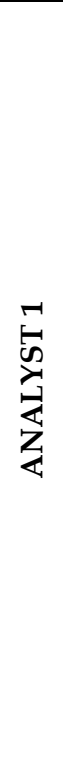 } & No & $\begin{array}{c}\text { Theoretical } \\
\text { Concentration } \\
(\mu \mathrm{g} / \mathrm{mL})\end{array}$ & Area-1 & Area- 2 & $\begin{array}{l}\text { Area- } \\
\text { Mean }\end{array}$ & $\begin{array}{c}\text { Practical } \\
\text { Concentration } \\
(\mu \mathrm{g} / \mathrm{mL}\end{array}$ \\
\hline & 1 & 20 & 148.63 & 145.99 & 147.31 & 21.140 \\
\hline & 2 & 20 & 139.28 & 147.89 & 143.59 & 20.595 \\
\hline & 3 & 20 & 145.25 & 152.55 & 148.90 & 21.373 \\
\hline & 4 & 20 & 141.45 & 149.19 & 145.32 & 20.849 \\
\hline & 5 & 20 & 146.66 & 147.21 & 146.94 & 21.086 \\
\hline & 6 & 20 & 145.72 & 142.69 & 144.21 & 20.686 \\
\hline & 7 & 20 & 149.67 & 143.98 & 146.83 & 21.069 \\
\hline & 8 & 20 & 150.94 & 150.45 & 150.69 & 21.636 \\
\hline & 9 & 20 & 155.30 & 148.13 & 151.71 & 21.785 \\
\hline & 10 & 20 & 154.10 & 148.83 & 151.47 & 21.749 \\
\hline & & & & & Mean & 21.197 \\
\hline & & & & & SD & 0.406 \\
\hline & & & & & $\%$ RSD & 1.917 \\
\hline \multirow{14}{*}{ 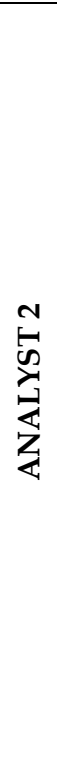 } & No & $\begin{array}{c}\text { Theoretical } \\
\text { Concentration } \\
(\mu \mathrm{g} / \mathrm{mL})\end{array}$ & Area-1 & Area- 2 & $\begin{array}{l}\text { Area- } \\
\text { Mean }\end{array}$ & $\begin{array}{c}\text { Practical } \\
\text { Concentration } \\
(\mu \mathrm{g} / \mathrm{mL}\end{array}$ \\
\hline & 1 & 20 & 146.90 & 151.06 & 148.98 & 21.385 \\
\hline & 2 & 20 & 145.62 & 148.40 & 147.01 & 21.097 \\
\hline & 3 & 20 & 141.95 & 152.50 & 147.23 & 21.128 \\
\hline & 4 & 20 & 152.82 & 147.86 & 150.34 & 21.584 \\
\hline & 5 & 20 & 155.70 & 148.36 & 152.03 & 21.832 \\
\hline & 6 & 20 & 147.57 & 142.67 & 145.12 & 20.820 \\
\hline & 7 & 20 & 157.06 & 151.23 & 154.15 & 22.141 \\
\hline & 8 & 20 & 151.98 & 147.54 & 149.76 & 21.499 \\
\hline & 9 & 20 & 144.85 & 152.23 & 148.54 & 21.321 \\
\hline & 10 & 20 & 157.78 & 143.77 & 150.78 & 21.648 \\
\hline & & & & & ORT & 21.445 \\
\hline & & & & & sS & 0.365 \\
\hline & & & & & \%VK & 1.700 \\
\hline
\end{tabular}


The solution of HA active substance, which was prepared at a concentration of $60 \mu \mathrm{g} / \mathrm{mL}$ using the mobile phase, was measured in HPLC at 15, 30, 60 and 120 minutes and 24 and 48 hours and it was determined whether there was any change in the values. The results obtained are shown in Table 6.

The specificity of the HPLC method is demonstrated by the separation of the analytes from other potential components such as impurities, degradants, or excipients [16, 17]. In this regard, the optimum amount of contents in microemulsion formulation for IPM, Tween 80, ethanol and $0.9 \% \mathrm{NaCl}$ solution were found $7.02 \%, 25.575 \%, 25.575 \%, 41.83 \%$, respectively.

Table 5. Area and standard deviation (SD) values of the $5 \mathrm{ppm}$ sample to calculate LOD and LOQ values.

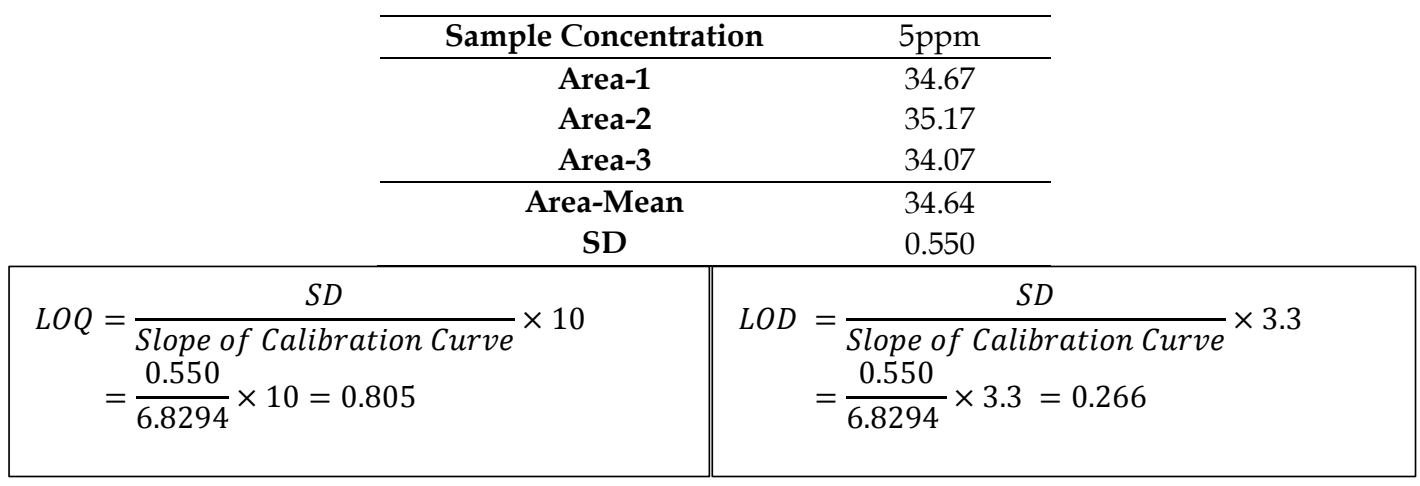

Table 6. Stability test results for $60 \mu \mathrm{g} / \mathrm{mL}$ concentration ( $\mathrm{p}>0.05)$.

\begin{tabular}{|c|c|c|c|c|c|c|c|}
\hline Time & $0 \mathrm{~min}$ & $15 \mathrm{~min}$ & $30 \mathrm{~min}$ & $60 \mathrm{~min}$ & $120 \mathrm{~min}$ & $24 \mathrm{~h}$ & $48 \mathrm{~h}$ \\
\hline Area-1 & 417.67 & 421.94 & 412.50 & 418.24 & 420.81 & 406.79 & 400.49 \\
\hline Concentration-1 & 60.728 & 61.278 & 59.898 & 60.737 & 61.113 & 59.063 & 58.142 \\
\hline Area-2 & 417.62 & 415.00 & 410.24 & 429.89 & 420.17 & 404.96 & 405.42 \\
\hline Concentration-2 & 60.721 & 60.352 & 59.655 & 62.532 & 61.109 & 58.882 & 58.949 \\
\hline Area-3 & 408.42 & 419.52 & 411.08 & 424.04 & 405.86 & 394.60 & 407.11 \\
\hline Concentration-3 & 59.375 & 61.014 & 59.778 & 61.675 & 59.013 & 57.365 & 59.197 \\
\hline Area-Mean & 414.57 & 418.82 & 411.27 & 424.056 & 415.61 & 402.116 & 404.34 \\
\hline Concentration- Mean & 60.274 & 60.881 & 59.777 & 61.648 & 60.412 & 58.437 & 58.763 \\
\hline Concentration SD & 0.779 & 0.390 & 0.099 & 0.733 & 0.989 & 0.761 & 0.450 \\
\hline
\end{tabular}

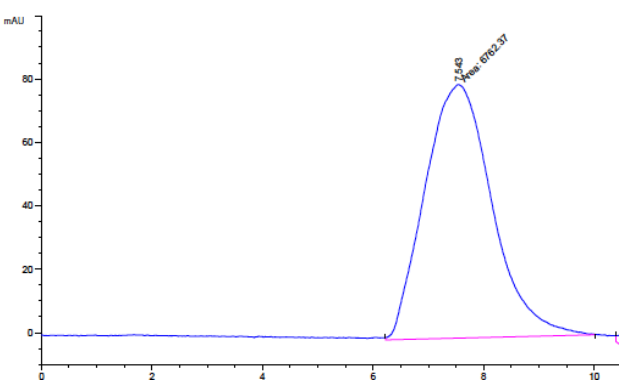

Figure 3. HPLC chromatogram of hyaluronic acid.

In order to prove that the field values in HPLC belong to the active substance, the field values of the HA solution (Figure 3), blank and the active substance loaded formulations were checked and the obtained HPLC chromatograms (Figure 4).

No interaction was found in between peaks of HA and the components of the microemulsion formulation and also the impurities. The retention time of the HA peak was at $7.543 \mathrm{~min}$. The chromatogram blank microemulsion formulation (Figure 4a) showed no peak and retention time as well. The chromatogram of the formulation loaded with HA is Figure $4 \mathrm{~b}$. Drug content analysis of HA loaded microemulsion was found $9.9 \pm 0.2 \mathrm{mg} / \mathrm{mL}$.

The HPLC method of HA has been developed and the method has been validated. Validation was evaluated in terms of linearity, accuracy, precision, specificity, and stability parameters according to the criteria recommended by the FDA. The determination coefficient $\left(R^{2}\right)$, which indicates the linearity of the 
calibration curve, was found to be 0.9996 while examining in terms of linearity. In the accuracy study at different concentrations, the accuracy values (\%) calculated as a result of three parallel injections at the same concentration are above $90 \%$. In evaluating the validation in terms of specificity, the HA peak came in almost 8 minutes as seen only in the mobile phase and the injection with the HA mobile phase, and no active ingredient peak was observed before and after this period in the empty injection.

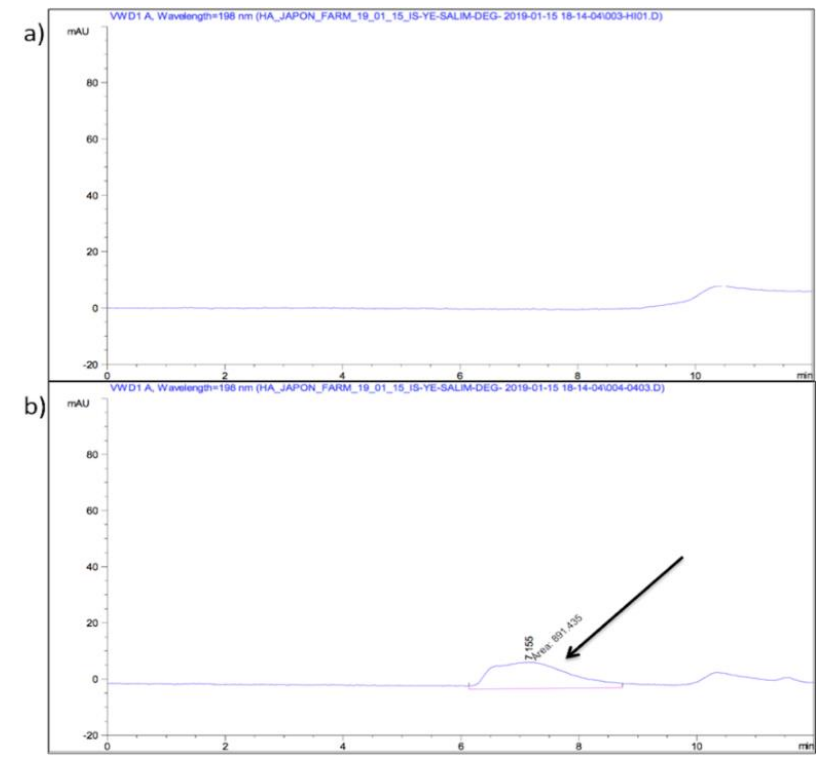

Figure 4. a) HPLC chromatogram of blank in microemulsion formulation, b) HPLC chromatogram of formulation loaded with hyaluronic acid.

\section{CONCLUSION}

In this study, a simple, accurate, precise HPLC method has been developed for simultaneous testing of hyaluronic acid. ICH guideline was used to validate the method. Results showed that the developed method is applicable for intended analysis because it has proven that the method is accurate and precise quantitative results under small variations of chromatographic conditions. Furthermore, the high recovery and low relative SD proved that this method is suitable for determining HA in dosage forms. Consequently, this method can routinely be used for HA determination.

\section{MATERIALS AND METHODS}

\subsection{Materials}

HA was a kind gift from Kuzey Kimya, Turkey. Sodium sulfate, sodium azide and sodium chloride were purchased from Sigma-Aldrich (Germany). IPM was obtained from Sigma, USA. Tween 80 and ethanol were purchased from Merck, Germany. ELGAFlex water system (UK) was used to obtain ultrapure water. Rest of the chemicals used were analytical grade.

\subsection{Methods}

\subsubsection{Instrumentation}

An HP Agilent 1100 series HPLC system (USA) equipped with a solvent pump, thermostable column, injection valve and a UV detector were used. The separation of compound was achieved with a OHpak Shodex SB-806M HQ (13 $\mu \mathrm{m}, 8,0 \times 300 \mathrm{~mm}$, Japan) analytical column and also a guard column which is OHpak SB-G, ( $8 \mu \mathrm{m}, 100 \AA, 6.0 \times 50 \mathrm{~mm}$, Japan) was integrated to the system before the analytical column.

\subsubsection{Chromatographic conditions}

UV spectrometer (UV-1800-Shimadzu, Japan) was used to analyze the HA samples. The HA sample was analyzed in the range of 190-800 nm. The optimum wavelength was found as $198 \mathrm{~nm}$ (Figure 5). This wavelength is the wavelength of maximum response of $\mathrm{HA}$ in the mobile phase and it lets simultaneous determination of related impurities of HA. 


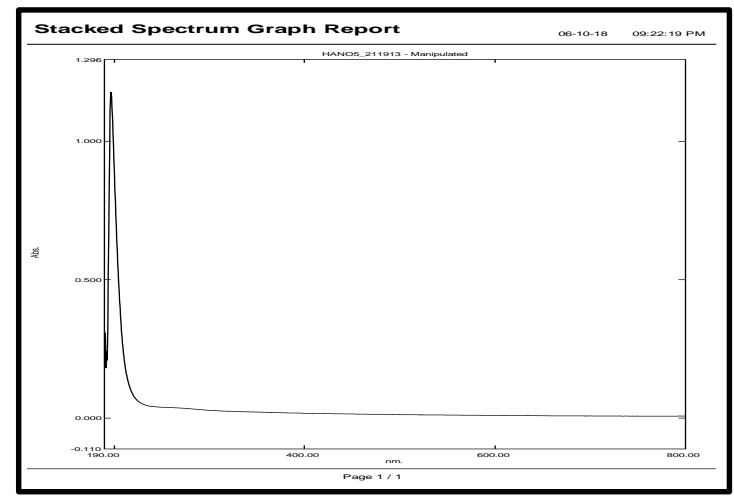

Figure 5. UV spectrum of hyaluronic acid.

The mobile phase was $0.1 \mathrm{M} \mathrm{Na}_{2} \mathrm{SO}_{4}$ and delivered at a flow rate of $1 \mathrm{~mL} / \mathrm{min}$ which gave the best resolution within acceptable analysis time and column back pressure. The injection volume was $20 \mu \mathrm{L}$. The UV detector was operated at $198 \mathrm{~nm}$. In addition, column was heated $40{ }^{\circ} \mathrm{C}$ throughout the analysis. The column was equilibrated for at least 1 hour with the mobile phase flowing through the system before the injection of the drug standards. The run time was set at $10 \mathrm{~min}$ with the system operating. The mobile phase was filtered and degassed through membrane filter of $0.22 \mu \mathrm{m}$ porosity under vacuum.

\subsubsection{Preparation of stock solutions and standard working solution}

$10 \mathrm{mg} \mathrm{HA}$ was dissolved in $100 \mathrm{~mL} 0.9 \% \mathrm{NaCl}$ solution in order to prepare stock solution of HA, so 100 $\mu \mathrm{g} / \mathrm{mL}$ stock solution was prepared. The prepared stock solutions were stored in the refrigerator at $4 \pm 1{ }^{\circ} \mathrm{C}$ in a clear glass volumetric flask and covered with aluminum foil in terms of light protection. 5, 10, 20, 40, 60, 80, $100 \mathrm{\mu g} / \mathrm{mL}$ HA concentrations in working solutions were chosen for the aim of drawing calibration curve. Dilution of stock solution in mobile phase was used to prepare further daily fresh working solutions. An aqueous $0.2 \mu \mathrm{m}$ pore size membrane filter was used for all solutions to be filtered before injection.

\subsubsection{Preparation and content determination of microemulsion formulation}

The existence range of microemulsions was understood by using pseudo-ternary phase diagram. Microemulsion formulation was prepared by titration method [18]. In order to prepare microemulsion, IPM as oil phase, Tween 80 as surfactant, Ethanol as cosurfactant and $0.9 \% \mathrm{NaCl}$ solution as aqueous phase were used. HA was loaded microemulsion to a final concentration of $10 \mathrm{mg} / \mathrm{mL}$. In order to determine the amount of HA in microemulsion, HA loaded formulation was dissolved in mobile phase and the amount of HA was analyzed by using HPLC.

\subsubsection{Validation of HPLC method}

The validation parameters consisted at system suitability, linearity, limit of detection (LOD) and quantitation (LOQ), precision, accuracy and specificity, selectivity, and stability.

\subsubsection{Linearity}

The calibration curve was used to analyze the linearity between peak area and concentration. For the drawing of the calibration curve, samples diluted in mobile phase from the stock solution to concentrations of $5,10,20,40,60,80,100 \mu \mathrm{g} / \mathrm{mL}$ were examined in parallel in three. After each injection, the area value observed in HPLC was plotted against concentration and the calibration curve was drawn. The equation of the line and the $\mathrm{R}^{2}$ value are calculated.

The peak area of each concentration at which retention time and maximum absorption was obtained as a result of injection of standard solutions into HPLC was calculated. HA concentration versus peak areas were plotted and the calibration equation was determined. Each measurement was repeated 3 times.

\subsubsection{Accuracy and recovery}

The accuracy of an analytical method is defined as the closeness of test results obtained by the method to the true value. Field values of three parallel samples at three different concentrations $(20,40$, and $60 \mu \mathrm{g} / \mathrm{mL})$ were measured. The concentration amount corresponding to this area value was found by placing it in the calibration equation. Percentage recovery from the found value was calculated with the help of Equation 1 [9]. 


$$
\% \text { Recovery }=\left(C_{\text {practical }} / C_{\text {theoretical }}\right) \times 100(E q .1)
$$

$\mathrm{C}_{\text {practical }}$ Concentration value obtained from the calibration equation of active substances

$\mathrm{C}_{\text {theoretical: }}$ Concentration value of the active substance

\subsubsection{Precision}

Precision is a measure of the degree of repeatability and reproducibility of the analytical method under normal operating conditions. It is performed by measuring the samples in the same concentration, in the number of statistically sufficient evaluations, and calculating the arithmetic mean, standard deviation (SD) and coefficient of variation (RSD\%). RSD \% less than $2 \%$ shows that the method provides precision. Accordingly, the standard solution at the same concentration $(60 \mu \mathrm{g} / \mathrm{mL})$ was measured fifteen times consecutively, and mean, SD and RSD\% were calculated [19]. Accuracy and precision values were calculated at the lowest and highest concentrations of the working range $(5 \mu \mathrm{g} / \mathrm{mL}$ and $100 \mu \mathrm{g} / \mathrm{mL})$ for analytical method validation in line with the guidelines of the International Harmonization Conference (ICH) [20].

\subsubsection{Stability of the solution}

The solution prepared at a concentration of $60 \mu \mathrm{g} / \mathrm{mL}$ using the mobile phase of the HA active ingredient was measured at 15, 30, 60 and 120. minutes and 24 and 48 hours in HPLC and it was determined whether there was any change in the values. Each measurement was repeated 3 times.

\subsubsection{Repeatability}

A concentration $(40 \mu \mathrm{g} / \mathrm{mL})$ was selected from the stock solution prepared to create the calibration equation, and the solutions at this concentration prepared on two different days were injected into the HPLC ten times consecutively. The mean, SD and RSD \% of the concentrations corresponding to the area value were calculated. The fact that the method is repeatable shows that the RSD \% is less than $2 \%$.

\subsubsection{Reproducibility}

For the reproducibility study, the area values of ten solutions of the same concentration $(20 \mu \mathrm{g} / \mathrm{mL})$ prepared by dilution by 2 different analysts, starting from the same stock, were tested and the mean, SD and RSD \% of the obtained values were calculated. The recoverability of the method indicates that the RSD \% is less than $2 \%$.

\subsubsection{Specificity/Selectivity}

In order to prove that the field values found as a result of working with the formulations in HPLC belong to the active substance, the formulations without hyaluronic acid loaded and the active substance loaded formulations were read in HPLC and it was checked whether the HPLC field value of the HA active substance was separate from the field value of the empty formulation [21].

\subsubsection{Limit of quantification and detection}

Quantitation of HA should be able to analyze the expected concentrations easily and accurately. The limit of detection (LOD) is the lowest concentration at which the analyzed substance can be determined with acceptable accuracy and repeatability. The limit of quantitation (LOQ) is the lowest concentration at which the analyzed substance can be detected. These limits were determined by analyzing a series of low concentration samples. In the calibration equation, the SS values of the areas corresponding to the lowest value were calculated and the average of these values was divided by the slope of the selected calibration curve and multiplied by 3.3, the detection limit (Equation 2) was multiplied by 10 and the limit of determination (Equation 3) was determined. In LOD and LOQ studies, 3 samples were studied. $\sigma$ is the standard deviation of the given sample; $\mathrm{S}$ refers to the slope of the calibration curve [22]

$$
L O Q=\frac{10 \times \sigma}{\mathrm{s}}(\mathrm{Eq} .3) \quad L O D=\frac{3.3 \times \sigma}{\mathrm{s}}
$$


Acknowledgements: This study was supported by TUBITAK Project No: $117 \mathrm{~S} 435$

Author contributions: Concept - N.Ü.O., H.Y.K..; Design - N.Ü.O., H.Y.K.; Supervision - N.Ü.O., H.Y.K.; Resources E.Ş.Ç., N.Ü.O., H.Y.K..; Materials - E.Ş.Ç., N.Ü.O., H.Y.K..; Data Collection and/ or Processing - E.Ş.Ç., N.Ü.O., H.Y.K..; Analysis and/or Interpretation - E.Ş.Ç., N.Ü.O., H.Y.K..; Literature Search - E.Ş.Ç., N.Ü.O., H.Y.K..; Writing - E.Ş.Ç., N.Ü.O., H.Y.K..; Critical Reviews - E.Ş.Ç., N.Ü.O., H.Y.K.

Conflict of interest statement: The authors declared no conflict of interest.

\section{REFERENCES}

[1] Sudha PN, Rose MH. Beneficial Effects of Hyaluronic Acid. Adv Food Nutr Res. 2014; 137-176. [CrossRef]

[2] Gerwin N, Hops C, Lucke A. Intraarticular Drug Delivery in Osteoarthritis. Adv Drug Deliv Rev. 2006; 58: $226-242$. [CrossRef]

[3] Kuo JW, Swarm DA, Prestwich GD. Chemical Modification of Hyaluronic Acid by Carbodiimides. Bioconjug Chem. 1991; 2: 232-241. [CrossRef]

[4] Ito T, Yeo Y, Highley CB, Bellas E, Benitez CA, Kohane DS. The Prevention of Peritoneal Adhesions by In Situ CrossLinking Hydrogels of Hyaluronic Acid And Cellulose Derivatives. Biomaterials. 2007; 28: 975-983. [CrossRef]

[5] Yeo Y, Highley CB, Bellas E, Ito T, Marini R, Langer R, Kohane DS. In Situ Cross-Linkable Hyaluronic Acid Hydrogels Prevent Post-Operative Abdominal Adhesions in A Rabbit Model. Biomaterials. 2006; 27: 4698-4705. [CrossRef]

[6] Shen H, Shi S, Zhang Z, Gong T, Sun X.. Coating Solid Lipid Nanoparticles with Hyaluronic Acid Enhances Antitumor Activity Against Melanoma Stem-Like Cells. Theranostics. 2015; 5: 755-771. [CrossRef]

[7] Kašparová J, Arnoldová K, Korecká L, Ceslova L.. Determination of Hyaluronic Acid in Pharmaceutical Products by Spectrophotometry and HPLC Coupled to Fluorescence or Mass Spectrometric Detection. Fac Chem Technol. 2018; 24: 39-47.

[8] Saari H, Konttinen YT, Friman C, Sorsa T. Differential Effects of Reactive Oxygen Species on Native Synovial Fluid And Purified Human Umbilical Cord Hyaluronate. Inflammation. 1993; 17: 403-415. [CrossRef]

[9] Ruckmani K, Shaikh SZ, Khalil P, Muneera MS, Thusleem OA. Determination of Sodium Hyaluronate in Pharmaceutical Formulations by HPLC-UV. J Pharm Anal. 2013; 3: 324-329. [CrossRef]

[10] Trathnigg B. Size-exclusion Chromatography of Polymers. Meyers R., editor. John Wiley \& Sons, Ltd; 2000. [CrossRef]

[11] Ustündağ Okur N, Yavaşoğlu A, Karasulu HY. Preparation and Evaluation of Microemulsion Formulations of Naproxen For Dermal Delivery. Chem Pharm Bull. 2014; 62: 135-143. [CrossRef]

[12] Üstündağ Okur N, Çağlar EŞ, Pekcan AN, Okur ME, Ayla Ş. Preparation, optimization and in vivo anti-inflammatory evaluation of hydroquinone loaded microemulsion formulations for melasma treatment. J Res Pharm. 2019; 23: 662670. [CrossRef]

[13] Gremião MPD, Cocenza Urban MC, Mainardes RM, et al. Development and Validation of HPLC Method for Analysis of Dexamethasone Acetate in Microemulsions. Brazilian J Pharm Sci. 2009; 45(1): 87-92 [CrossRef]

[14] Md Sabir A, Moloy M, Parminder BS. HPLC Method Development and Validatıon: A Review. Int Res J Pharm. 2013; 4: 39-46.[CrossRef]

[15] Soo Lim H, Young Hwang J, Choi EA, Gunyoung L, Yoon SS, Kim M. Development And Validation of HPLC Method for The Determination of Ferrocyanide Ion in Food Grade Salts. Food Chem. 2018; 239: 1167-1174. [CrossRef]

[16] Batrawi N, Naseef H, Al-Rimawi F. Development and Validation of a Stability-Indicating HPLC Method for the Simultaneous Determination of Florfenicol and Flunixin Meglumine Combination in an Injectable Solution. J Anal Methods Chem. 2017; 2017: 1529280. [CrossRef]

[17] Landim LP, Feitoza GS, da Costa JGM. Development and Validation of a HPLC Method for The Quantification of Three Flavonoids in A Crude Extract of Dimorphandra Gardneriana. Brazilian J Pharmacogn. 2013; 23: 58-64. [CrossRef]

[18] Üstündağ Okur N, Er S, Çağlar EŞ, Ekmen TZ, Sala F. Formulation of Microemulsions for Dermal Delivery of Cephalexin. Acta Pharm Sci. 2017; 55: 27-40. [CrossRef]

[19] Motohash1 N, Morı I. Quantitation of Hyaluronic Acid and Chondroitin Sulphates in Rabbit Synovial Fluid by HighPerformanc Liquid Chromatography of Oligosaccharides Enzymatically Derived Thereof. Chem Pharm Bull. 1990; 38: 769-773. [CrossRef] 
[20] ICH Expert Working Group. International Conference on Harmonisation of Technical Requirements for Registration of Pharmaceuticals for Human Use, ICH harmonised tripartite guideline validation of analytical procedures: text and methodology Q2(R1) [Internet]. Fed. Regist. Vol. 62, No. 96. 1997 [cited 2020 Dec 10]. Available from: https://www.ich.org/fileadmin/Public_Web_Site/ICH_Products/Guidelines/Quality/Q2_R1/Step4/Q2_R1_G uideline.pdf.

[21] Urban MCC, Mainardes RM, Gremião MPD. Development and Validation of HPLC Method For Analysis of Dexamethasone Acetate in Microemulsions. Brazilian J Pharm Sci. 2009 ; 45: 87-92. [CrossRef]

[22] Food and Drug Administration. Analytical Procedures and Methods Validation for Drugs and Biologics [Internet]. Guid. $\quad$ Ind. 2015 [cited $2020 \quad$ Nov 24]. Available from: http://www.fda.gov/Drugs/GuidanceComplianceRegulatoryInformation/Guidances/default.htm.

This is an open access article which is publicly available on our journal's website under Institutional Repository at http://dspace.marmara.edu.tr. 